which it occurs; indeed, it is not known whether silicon is, or is not, an essential tissue constituent. The fact that a part of the silicon in dried tissue is soluble in alcohol ${ }^{17,18}$ has been taken to indicate that some of the silicon is in organic combination. These experimental findings have been confirmed in our laboratory by using isotopically marked silicon incorporated in silicic acid. There is no evidence, however, that the formation of the alcohol-soluble compounds requires biological activity.

1 Gye, W. E., and Purdy, W. J., Brit. J. Exp. Path., 3, 75 (1922).

2 Carman, H., Trans. Farad. Soc., 36, 964 (1940).

${ }^{3}$ King, E. J., Stantial, H., and Dolan, M., Biochem. J., 27, 1002 (1933)

4 Gye, W. E., and Purdy, W. J., Brit. J. Exp. Path., 3, 86 (1922).

${ }^{5}$ Banting, F. S., Can. Med. Assoc. J., 289 (1936).

- Kettle, E. H., J. Bact. and Path., 35, 395 (1932).

"Gardner, L. V., and Cummings, D. F., Amer. J. Path. (Supp.), 9, 751 (1933).

${ }^{8}$ Jemon, W. S., and Higgins, G. M., Amer. Rev. Tuberc., 28, 470 (1933)

- Fallon, J. T., and Banting, F. G., Can. Med. Assoc.J., 33, 404 (1935)

${ }^{10}$ Briscoe, H. V. A., Holt, P. F., Matthews, J. W., and Sanderson, P. M., Trans. Inst. Min. and Metall., 46, 291 (1937).

11 King, E. J., Med. Res. Council, Spec. Rep. Ser. No. 250 (1945).

${ }^{12}$ Holt, P. F., and Briscoe, H. V. A., Nature, 163, 334 (1949). ${ }^{13}$ King, E. J. Wright, B. M., Roy, S. C., and Harrison, C. V., Brit.

14 King, E. J., Uccup. Med., 4, 26 (1947).

${ }^{15}$ Wright. B. M., Nature, 166, 538 (1950)

10 Middleton, E. L., Lancet, i (July 4, 1936).

${ }^{17}$ Holzapfel, L., Naturniss., 30, 185 (1942).

${ }_{18}$ Ohlmeyer, P., and Olpp, U., Hoppe-Seylers Z., 281, 203 (1944).

${ }^{19}$ Holt, P. F., Brit. J. Indust. Med., 7, 12 (1950).

\section{NOTCHED BAR TESTING OF MILD STEEL}

$\mathrm{O}$ December 5, 1951, a symposium on "Notched Bar Testing and its Relation to Welded Construction" was held in the buildings of the Institution of Civil Engineers. It was organized by the Institute of Welding in association with the Joint Committee on Materials and their Testing, and Prof. E. C. Rollason was in the chair. Five papers were presented, and after being introduced by Dr. N. P. Allen, acting as rapporteur, were very fully discussed by a gathering of ongineers and metallurgists, including many authorities from the Continent of Europe.

Notched bar testing, by which is generally meant the measurement of the energy required to break with a single blow a notched bar of standard form, has been an accepted feature of the testing of heattreated alloy steels for many years. Its application to ordinary structural mild steel has developed during the past five or ten years, and is a direct consequence of the introduction of welded construction. When riveted construction is used, a few plates or sections of inferior quality may be employed without the whole structure being endangered. A crack developing in a faulty plate will usually spread no farther than the edge of the plate. But when the members are welded together into an effectively continuous and rigid structure, a crack formed at a local fault can spread indefinitely and may bring about the failure of the whole structure. Catastrophic failures have occurred in welded bridges and in welded ships, and have been the cause of much bitter controversy.

Although inquiries into these failures have revealed many defective practices, it has ultimately been recognized that structural mild steel may meet the ordinary specification tests in every particular, and yet lack an ability to offer resistance to the spread of a crack which another mild steel, not noticeably superior in its purity or specified properties, may possess in a marked degree. The inability to resist the spread of a crack is accompanied by an absence of plastic deformation in the neighbourhood of the crack, and is commonly described as susceptibility to 'brittle fracture'. It has been found to be to some extent associated with a low absorption of energy and a crystalline fracture in a notched bar test. Consequently a demand has arisen that mild steels for welding be subjected to some form of notched bar test. It is, however, well known that very strict control over every detail of manufacture is necessary to ensure consistent performance in these tests. Their introduction will restrict the steel-maker's freedom of action and, according to the severity of the test, may increase the cost of the steel and handicap the purchaser in his markets. It is therefore most important that a form of test be adopted which, while providing an adequate degree of security, shall not add unnecessarily to the steel-maker's burdens.

The five papers presented at the symposium comprised two written by steel-makers, and three written by representatives of the user. W. Barr and I. M. Mackenzie considered that the real use of notched bar tests is to guide the steel-makers in the choice of practices for making safe steels. As a result of their systematic use, the steel-maker is already able to supply mild steels in several recognizable grades of resistance to brittle fracture. It remains for the user to decide in the light of experience which grade he requires, and to arrange his testing to ensure that this grade is received. In any notched bar test, a mild steel breaks with a fibrous fracture, characteristic of great resistance to the spread of a crack, if the temperature is high, and with a crystalline fracture characteristic of brittle behaviour if the temperature is low. There is a 'transition temperature', more or less well marked, at which the behaviour of the steel changes, and the quality of the steel in respect of its resistance to brittle fracture is better the lower its transition temperature. If notched bar testing is to be introduced into specifications for mild steel (which, incidentally, these authors did not think necessary) a 10-mm. square bar with an Izod $V$-notch, as used in current British specifications for alloy steels, is as good a test as any; but the tem. perature at which the test is performed should be chosen so as to be in the middle of the expected 'transition temperature range' of the steel. A high absorption of energy in breaking the test-piece will then indicate that the transition-temperature range of the sample is on the whole below the test temperature, and a low absorption of energy that it is on the whole above the test temperature.

G. M. Boyd, who presented a review of comparative tests made with different standard types of notched bar, did not entirely agree with this view. He concluded that it is impossible to correlate the results of different kinds of notched bar test in any simple way. The essential reason is that the energy consumed in breaking a notched bar is composed of the energy required to initiate the crack at the root of the notch and that required to propagate the crack through the section, and that these two energies play different parts in every steel and type of test. In his opinion, small notched bars such as the standard Izod testpiece suffer from the disadvantage that the energy required to initiate the crack is too large a proportion of the total energy. In practice, the initial crack is 
too often already present, as a result either of defective welding or of accidents in service, and the energy required to extend the crack is the only really important factor. To emphasize its importance, large test-pieces should be employed, and more attention given to the type of fracturo-whether accompanied by plastic deformation or not-than to the energy absorbed.

Similar opinions were expressed by Mrs. C. F. Tipper in an account of tests of plates taken from welded ships that had developed cracks in service. In one case, standard Izod impact tests made on small pieces cut from the plate gave the impression that the steel was quite tough at the temperature at which the failure had occurred, whereas tensile tests on considerably larger test-pieces showed clear signs of the onset of brittleness at the same temperature. Mrs. Tipper feared that the use of the existing standard notched bar tests might cause the danger of brittle fractures in ordinary mild steel to be seriously under-estimated and a too optimistic view to be taken of the degree of improvement that is required.

Dr. J. H. van der Veen described an interesting test developed and used by him for testing mild-steel plate at the Royal Netherlands Steel Works. He makes use of a bar, $225 \mathrm{~mm}$. long and $70 \mathrm{~mm}$. wide, and of the full plate thickness, which is slowly bent on edge, as a beam. A small sharp notch, pressed in at the middle of the tension edge, ensures that a crack is formed very early in the test. The mechanical resistance of the beam is measured as the crack spreads through the section, and the nature of the fracture is recorded at the end of the test. If the plate is tough at the temperature of test, the fracture is fibrous throughout, and the resistance of the testpiece rises smoothly to a maximum as the crack lengthens. It then falls gradually to zero. If there is any tendency to brittleness, a point is reached at which the resistance of the test-piece falls suddenly, and the fracture at the same time changes from a fibrous to a crystalline appearance. This change occurs earlier in the test, and the area of the crystal. line part of the fracture is greater in plates which are deficient in their ability to resist the spread of a crack ; and the test can be used to define a 'transition temperature' below which the toughness of the plate decreases considerably. This type of test has been used before. Dr. van der Veen has worked out its application in detail, and in his hands it has proved to be very discriminating.

Finally, Prof. W. Soete gave an account of an experimental method for measuring the triaxiality ratio of the stress condition produced by a circumferential notch in a tensile test-piece. The brittle behaviour of a notched bar is largely due to the high degree of triaxiality of stress induced by a sharp notch; and Prof. Soete was able to show that in certain steels the triaxiality of stress produced by a given notch is not markedly influenced by the amount of deformation applied to the test-piece, but is highly dependent upon the temperature at which the deformation is applied.

During the discussion of the papers, it became very clear that certain users of welded mild steel intend to insist upon the introduction of some form of notched bar test for mild-steel plate. Not only must the plate be tested, but also the quality of the weld metal with which the plates are joined, and of the adjacent heat-affected zones, must be controlled, for cracks often originate in welds or their heat-affected zones. Although the use of large test-pieces may be desirable from some points of view, too great reliance on large test-pieces is not to be encouraged, for some form of test-piece must be available that can be used for testing small volumes of weld metal and heat-affected material. Several speakers referred to the varying degrees of brittleness exhibited by the weld deposits laid down by electrodes having different types of coating, and it was also pointed out that weld metal is sometimes cold-worked by hammering, and that some weld metals may be seriously embrittled by this operation.

T. S. Robertson stated that the resistance of most steels to the spread of a crack is appreciably lowered by even small amounts of cold work, and that this constitutes an objection to the common forms of notched bar test, in which the steel is inevitably deformed before a crack is produced, and the resistance of the undeformed material to the propagation of a crack is never measured. He described an ingenious experiment in which a strip cut from a plate is cooled at one end to a temperature at which it is quite brittle, and a fine crack produced at the cold end of the strip is forced by the application of stress to spread towards the other end, which is warmed. It is found that in any steel the crack spreads in a brittle manner for a certain distance, until a point is reached at which the temperature is such that the crack will no longer spread unless the steel is plastically deformed. This temperature is characteristic of the steel and is lower in the more crack-resistant steels. The experiment demonstrates the essential property that is required in a steel if it is to resist brittle fracture, but it is too complex to be the basis of a practical test. The value of the simple notched bar test was, however, confirmed by N. G. Leider, who reported that in a Swedish shipyard, where several minor failures of welded structures had occurred, the incidence of failures had been successfully correlated with the results of notched bar tests. Other speakers reported similar experiences.

The principal difference of opinion, however, was concerned with the method of assessing the results of the notched bar test. On one side, it was contended that a structure has failed for all practical purposes if a crack is produced in it, and that the greatest importance should be given to the resistance offered by the material to the initiation of a crack. On the other side, it was asserted that, no matter what precautions are taken, cracks will occur now and then, and that a dangerous structure is one in which the cracks can spread suddenly and catastrophically. From this point of view the initiation of the crack is unimportant, and the energy absorbed in its propagation is paramount. This difference occupied much of the discussion; but it is academic, since in practice the steels that offer a large resistance to the initiation of a crack also offer, as a rule, a large resistance to its propagation. It should not be allowed to obscure the important points upon which all contributors to the discussion appeared to be agreed, and which may be summarized as follows.

(l) There is a need for the production of mild steel for welded structures which is of known and controlled quality in respect of its ability to resist the initiation and spread of a brittle fracture. (2) This quality can be judged by means of suitably applied notched bar tests, and, though different authorities may differ in the procedures they recommend, they will not commonly differ in their assessments of the 
relative merits of plates, unless the differences between the plates are small. (3) The present British Standards recommendations for notched bar tests are not suitable for the testing of mild-steel plates, and will require revision if the notched bar testing of mild-steel plates becomes common. In particular, the importance of the temperature of the metal under test is not sufficiently emphasized. (4) There is considerable uncertainty about the standard of quality in respect of resistance to brittle fracture that is required in steel for particular applications. Much study of this subject appears to be needed. (5) The resistance to brittle fracture of weld metal and the heat-affected zones of welds has not yet been sufficiently studied.

N. P. ArLen

\section{OBITUARIES}

\section{Sir Cyril Sankey Fox}

THe sudden death of Sir Cyril Fox in Calcutta on December 28, 1951, has come as a shock to all who knew him. Soon after arriving from England he fell ill with pneumonia, and then when apparently well on the way to recovery died suddenly of coronary thrombosis. Science has thus lost a distinguished exponent of engineering geology.

Cyril Sankey Fox was the son of John Henry Neat Fox, and was born in Calcutta on February 24, 1886. $\mathrm{He}$ obtained his technical education at the Civil Engineering College, Sibpur, and at the University of Birmingham, where he took the degree of B.Sc. in mining in 1908. He then spent some eighteen months underground at Cannock Chase Colliery, until he was recalled to the University of Birmingham as a lecturer in mining in 1910. (He took the degree of D.Sc. in mining in 1923.)

In 1911 Fox was appointed to the Geological Survey of India as assistant superintendent. He was promoted superintendent in 1930, and succeeded Dr. Heron as director on July 31, 1939. He was knighted in 1943 and retired from the service on January 1 , 1944.

Early in the First World War, Fox obtained a commission in the Royal Engineers, and was present at the battle of Loos in 1915 as Brigade Signals Officer, 15th (Scottish) Division. The close explosion of a shell during this action made Fox exceedingly deaf, and he was thereby greatly handicapped for the rest of his life.

In his early years in the Geological Survey of India, Fox was engaged on systematic surveying in the Central Provinces (in the party of the present writer), but after his recall, with other officers, from the war overseas, he was placed in charge of a mica mine at Jorasimar in Bihar. Thereafter his flair for economic and engineering geology was continuously utilized. Besides studying problems in water supply, dam sites and landslips, Fox made in turn surveys of India's bauxite and coal resources. For the latter survey Sir Edwin Pascoe formed a new Coalfields Party and placed Fox in charge. The results of this work spread over some years were presented in a series of memoirs on the geology and coal resources of the coalfields of India, all written by Fox himself (Mem. Geol. Surv. Ind., 57, 58, 59), except for that on the Raniganj Coalfield (61) by Dr. Gee and others. Besides contributing copiously to the departmental publications before he became director, Fox pub- lished separate books on bauxite (1927 and 1932), on engineering geology (1935), and, since his retirement, ore on the geology of water supply (1949), and another on water that has just appeared posthumously (1952).

Fox received charge of the Geological Survey of India at a very difficult time. With the outbreak of war the staff was promptly concentrated on work of economic importance, and Fox secured the sanction of the. Government of India to the formation of a Utilization Branch. $\mathrm{He}$ was thus able to employ mining engineers from Burma, rendered available by the Japanese invasion, for prospecting and developing mining propositions such as the lead-zinc deposit of Zawar in Rajputana. The invasion of Burma, and of a part of Assam, with its threat to Calcutta, threw an additional burden on the Geological Survey of India on account of the necessity of packing and removing from Calcutta collections of valuable specimens. In addition, the shortage of paper, and of lead for type, caused by the War, played havoc with the departmental publications, from which they have not yet recovered, in spite of the efforts of Dr. West during his period as director.

After retiring from the Survey, Sir Cyril Fox started a new career as a consulting geologist, and reported between 1944 and 1946 on the mineral resources of several Indian States. These reports, all published by the respective States and on sale, take the form of what the author calls a 'mineral audit' of the possibilities of each State. In 1947 he reported on the geology and mineral resources of the Dhufur Province, Muscat and Oman, in Arabia. At the time of his death, Sir Cyril had extended his operations to Egypt, and had built up a practice in which his services, particularly on problems of engineering geology, were in demand in Arabia, Egypt and India. He had taken a house in Wimbledon, London, from which he conducted his practice.

While in India, Sir Cyril had served as president of the Mining and Geological Institute of India (1936), of the Geological, Mining and Metallurgical Society of India (1943-45), and of the Royal Asiatic Society of Bengal (1942), of which he was made a Fellow in 1939. He was also president of the Geological Section of the Indian Science Congress in 1929. He was a founder member of the National Institute of Sciences of India (1935), a Fellow of the Geological Society of London (1909), and a member of the Institution of Mining Engineers.

Sir Cyril married Mabel Janet Dunn in 1916. Our sympathy must go out to Lady Fox in her unexpected loss.

L. L. Fermor

WE regret to announce the following deaths :

Dr. W. R. Ivimey Cook, senior lecturer in the Department of Botany, University College of South Wales and Monmouthshire, Cardiff, on February 1, aged fifty.

Dr. W. J. Elford, F.R.S., head of the Division of Physical Chemistry, National Institute for Medicai Research, Mill Hill, London, on February 14, aged fifty-two.

Dr. Max Hartmann, of the Pharmaceutical Department of Ciba Laboratories, Basle, where he was concerned in the production of coramine and other medicinal products, on February 2, aged sixty-seven.

Dr. Graham Renshaw, formerly a medical practitioner of Sale, Manchester, and well known as a naturalist, on January 13, aged seventy-nine. 